\title{
PENGEMBANGAN KOMODITAS BATIK: DETERMINASI BUDAYA EKONOMI DAN PERUBAHAN STRUKTUR KEBIJAKAN TERHADAP PERKEMBANGAN USAHA EKONOMI LOKAL (STUDI TENTANG PENGUSAHA BATIK LAWEYAN SURAKARTA)
}

\author{
Erma Setiawati \\ Fakultas Ekonomi dan Bisnis, Universitas Muhammadiah Surakarta \\ erma.setyowati@ums.ac.id \\ Nursiam \\ Fakultas Ekonomi dan Bisnis, Universitas Muhammadiah Surakarta \\ Zulfikar \\ Fakultas Ekonomi dan Bisnis, Universitas Muhammadiah Surakarta
}

\begin{abstract}
Batik is an Indonesian national culture product that awarded by UNESCO as world cultural heritage. The research takes place in Kampung Batik Laweyan Surakarta which is the oldest and the center of the traditional batik industry in Indonesia. The purpose of this research is 1) to understand the characteristics of economic culture to look at the social culture of Laweyan Batik business, 2) to explain the development of batik trading which is supported by informal economic opportunities, 3) to analyze the changes in political (policy) structure and its anticipating setrategy. This research is a qualitative research using ethnographic approach. The results showed that 1) batik entrepreneurs in Laweyan characterized as bazaar economy culture with reciprocity social relationships, 2) the business relationship is based on trust, 3) government policy on financial assistance for the development of batik Laweyan plays an important role as anticipation to free trade.
\end{abstract}

Keywords: cultural economics, business strategy, government policy

\section{PENDAHULUAN}

Batik merupakan salah satu budaya ciri khas bangsa Indonesia yang telah mendapat pengakuan dari UNESCO serta ditetapkan sebagai Warisan Kemanusiaan untuk Budaya Lisan dan Nonbendawi (Masterpieces of the Oral and Intangible Heritage of Humanity) sejak 2 Oktober 2009. Batik mempunyai keunggulan komparatif di bidang ekonomi, sehingga diharapkan mampu meningkatkan kesejahteraan masyarakat (Prasetyo 2010). Pada tahun 2008 industri batik nasional mencapai nilai ekspor US\$ 38 juta dan menyerap 603 ribu tenaga kerja, sedangkan 
unit usaha yang di industri batik ini adalah sebanyak 50.315 unit (Prasetyo 2010). Salah satu kota penghasil batik yang menjadikan sebagai komoditi andalan adalah Surakarta, dimana ekspor batik terus mengalami peningkatan, dari tahun 2006 sebesar \$2,496,539.46 sampai tahun 2010 sebesar \$10,196,173.12 (dalam Dollar Amerika). Negara-negara tujuan ekspor produksi Kota Surakarta antara lain Kanada, Cina, Perancis, Jerman, Amerika dan lain-lain. Menurut data dari Disperindag Surakarta terdapat 254 pengusaha batik yang tersebar di lima kecamatan yaitu kecamatan Laweyan terdapat sekitar 200 pengusaha, kecamatan Serengan terdapat empat pengusaha, kecamatan Pasar Kliwon terdapat 47 pengusaha, kecamatan Jebres terdapat tiga pengusaha (Disperindag Surakarta).

Kecamatan Laweyan memiliki kampung batik paling tua di Indonesia yaitu kampung batik Laweyan. Kampung ini juga merupakan sentra industri batik tradisional. Lokasi kampung batik Laweyan terletak di sebelah barat, kurang lebih 4 kilometer dari pusat Kota Surakarta. Kehidupan masyarakatnya sebagian besar masih bertahan dengan produksi batik, seolah-olah mereka menunjukkan eksistensinya dengan lingkungan sekitarnya. Produksi batik ini di pasarkan sebagian besar didalam negeri. Usaha batik Laweyan juga dinilai berkembang, dengan indikasi semakin bertambahnya jumlah pengusaha, ruang panjang serta peredaran usaha mereka.

Seiring dengan perubahan tatanan perekonomian dunia, maka perkembangan industri batik Laweyan diharapkan dapat mengantisipasi perubahan ini, ditandai dengan adanya globalisasi dan perdagangan bebas yang tidak lagi mengenal batas wilayah atau negara. Keadaan ini juga berdampak nyata kehidupan sosial dan budaya masyarakat. Globalisasi merupakan sebuah fenomena universal yang ditandai dengan perluasan dan integrasi pasar, baik di kalangan negara maju maupun negara berkembang. Perubahan sosial akibat globalisasi adalah meningkatkan perilaku konsumtif masyarakat termasuk pula perilaku konsumtif di kalangan anak-anak (Nugroho 1997).

Dengan dibukanya pintu perdagangan bebas, maka semakin banyak pilihan akan barang-barang kebutuhan misalnya pakaian batik. Masyarakat akan memilih barang yang murah dan berkualitas. Apakah kedua hal tersebut terdapat pada produk batik Laweyan? Dengan banyaknya persaingan ini maka kekuatan apa yang dapat mendorong pengusaha batik Laweyan untuk dapat bersaing dengan pengusaha batik lainnya yang berada di dalam maupun di luar negeri seperti Cina, Malaysia, Singapura dan lain-lain. Apabila dilihat dari beratnya pesaingan yang dialami pengusaha batik Laweyan, maka perlu strategi untuk dapat mempertahankan kelangsungan usaha batik dalam menghadapi era globalisasi.

Dengan adanya perdagangan bebas, maka perlu adanya campur tangan pemerintah untuk melindungi produk dalam negeri. Kebijakan pemerintah yang tertuang dalam UU No. 25 Tahun 1999 dan UU No. 33 tahun 2004 tentang Dana Perimbangan dengan diikuti peraturan daerah tentang APBD, diharapkan memegang 
peranan penting dalam mengantisipasi era perdagangan bebas. Ketepatan alokasi anggaran pada dana perimbangan tersebut memegang peranan penting dalam meningkatkan usaha batik di Laweyan dan sekitarnya.

Penelitian ini bertujuan untuk menganalisis budaya ekonomi kegiatan perdagangan batik yang didukung peluang-peluang ekonomi informal seperti hubungan-hubungan sosial yang bersifat ekonomi dengan mengandalkan trust dan menganalisis adanya perubahan struktur politik (kebijakan) terhadap pengusaha pribumi dan strategi-strategi yang dilakukan pengusaha batik Laweyan dalam menghadapinya.

Hasil penelitian ini nantinya diharapkan dapat memberi kontribusi bagi pengusaha lokal lainnya sehubungan dengan strategi-strategi yang digunakan agar pengusaha pribumi bisa bertahan. Bagi pengusaha batik Laweyan, hasil penelitian ini diharapkan dapat membantu dalam mengembangkan produk batik sehingga dapat tetap eksis di dunia bisnis. Bagi akademisi, hasil penelitian ini dapat digunakan sebagai acuan dan bahan pertimbangan untuk penelitian sejenis, sehingga penelitianpenelitian selanjutnya dapat menemukan keunggulan-keunggulan dari budaya ekonomi lokal lainnya.

\section{KAJIAN PUSTAKA}

\section{Teori Budaya Ekonomi}

Menurut Berger (dalam Wijaya 2008), budaya ekonomi merupakan cara pandang yang digunakan untuk memahami pola-pola tindakan, pikiran dan pengetahuan para anggota masyarakat dalam mengorganisasi produksi, distribusi dan pertukaran barang di pasar. Dalam perspektif budaya ada dua keterkaitan logis dalam memahami fenomena ekonomi yaitu intrinsic dan extrinsic linkage. Keterkaitan yang pertama menggambarkan keterhubungan antara dua variabel dimana variabel pertama sebagai prasyarat eksistensi variabel kedua, sedangkan sifat keterhubungan kedua lebih cenderung karena kebetulan (Wijaya 2008). Keterhubungan antara budaya dengan ekonomi bersifat timbal balik dan berlangsung secara bersama-sama dalam suatu totalitas empiris. Hubungan kausalitas tersebut tidak diasumsikan bahwa budaya menentukan ekonomi atau sebaliknya ekonomi sebagai determinan terhadap budaya.

Berger (dalam Wijaya 2008) menjelaskan penelitian empiris tentang lembaga-lembaga ekonomi akan menjelajahi konteks sosial budaya, dimana prosesproses ekonomi itu beroperasi. Lembaga-lembaga ekonomi tidak berada dalam ruang hampa, melainkan berada dalam suatu konteks struktur sosial, sub budaya dan proses sosial. Teori komprehensif tentang lembaga-lembaga ekonomi akan muncul melalui penelitian yang sistematis mengenai unsur-unsur yang saling terkait bersama dalam 
suatu totalitas empiris. Dengan kata lain, akan terjadi saling keterkaitan bersama antar unsur-unsur yang beroperasi dalam proses kelembagaan ekonomi.

Polanyi (dalam Wijaya 2008) mengungkapkan bahwa lembaga-lembaga ekonomi bertitik tolak dari bentuk integrasi perekonomian masyarakat, yaitu reciprocity, redistribution dan exchange. Perilaku timbal balik sebagai bentuk integrasi perekonomian masyarakat terjadi jika terdapat struktur dan organisasi sosial yang setara, seperti sistem kekeluargaan. Perilaku berbagi membentuk integrasi perekonomian masyarakat terjadi bila terdapat alokasi barang pada suatu pusat dengan mekanisme distribusi berlangsung menurut adat. Perilaku tukar-menukar merupakan bentuk integrasi perekonomian masyarakat yang terjadi jika terdapat mekanisme pasar.

\section{Teori Kebijakan Publik}

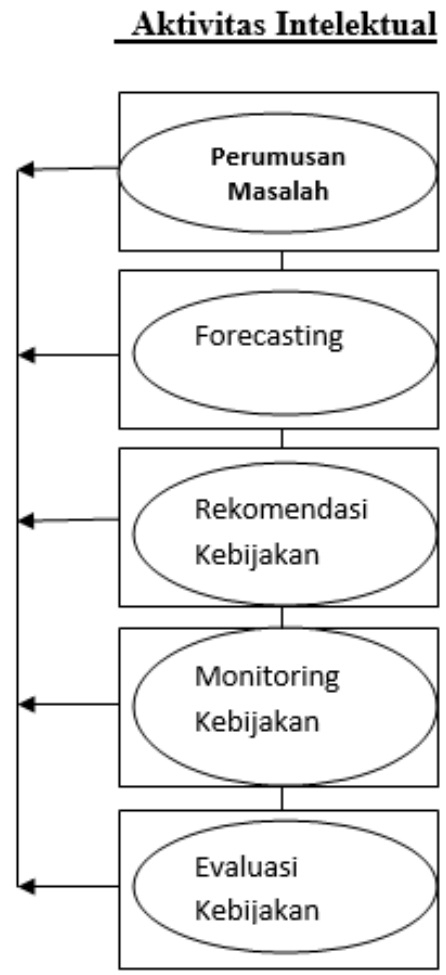

$\underline{\text { Aktivitas Politik }}$

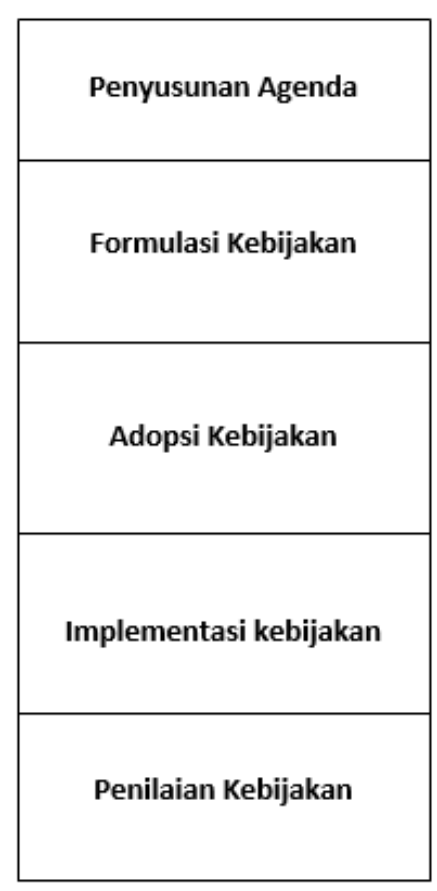

Sumber: Dunn (2004) dalam Suharsono (2008)

\section{Gambar 1 \\ Proses Kebijakan Publik}

Analisis proses kebijakan publik dilakukan dengan pendekatan teori yang dikemukakan oleh Dunn (2004) tentang proses kebijakan publik yang didefinisikan sebagai serangkaian aktivitas intelektual yang dilakukan dalam proses kegiatan yang bersifat politis. Aktivitas politis tersebut nampak dalam serangkaian kegiatan yang mencakup penyusunan agenda, formulasi kebijakan, adopsi kebijakan, implementasi dan penilaian kebijakan. Sedangkan aktivitas perumusan masalah, forecasting, 
rekomendasi, monitoring dan evaluasi kebijakan adalah aktivitas yang bersifat lebih intelektual. Analisis kebijakan terdiri dari tahapan-tahapan: perumusan masalah dengan penyusunan agenda, forecasting (peramalan) dengan formulasi kebijakan, rekomendasi kebijakan dengan adopsi kebijakan, monitoring kebijakan dengan implementasi kebijakan dan yang terakhir adalah evaluasi kebijakan dengan penilaian kebijakan ( Dunn 2004 dalam Suharsono 2008).

\section{METODA PENELITIAN}

\section{Pendekatan Penelitian}

Penelitian ini menggunakan metoda kualitatif dengan pendekatan etnografi. Pendekatan ini merupakan studi yang sangat mendalam tentang perilaku yang terjadi secara alami di sebuah budaya atau sebuah kelompok sosial tertentu untuk memahami sebuah budaya tertentu dari sisi pandang pelakunya (Meleong 1996)

\section{Subjek dan Lokasi Penelitian}

Subjek penelitian ini adalah para pengusaha batik yang memproduksi batik dan membuka showroom. Lokasi penelitian adalah di Kampung Laweyan Surakarta, dengan alasan: pertama, Kampung Laweyan adalah kampung batik tertua di Indonesia, kedua Kampung Laweyan merupakan pusat industri batik tradisional di Indonesia.

\section{Tahap-Tahap Penelitian}

Penelitian ini direncanakan selama kurun waktu satu tahun. Secara terperinci desain penelitian akan dibagi dalam tiga tahap yang dijelaskan sebagai berikut.

a. Tahap pertama

Penelitian tahap pertama ini adalah penelitian kualitatif dengan pendekatan etnografi, dengan langkah-langkah sebagai berikut.

(1) Melakukan survey untuk mendapatkan data pengusaha besar, menengah dan kecil pengusaha batik Laweyan. Data diambil dari Dinas Perindustrian, Perdagangan dan Koperasi Surakarta serta data dari FKPBL Laweyan. Pada tahun 2013, terdapat 11 unit usaha batik Laweyan yang memproduksi dan mempunyai showroom yang terdiri dari pengusaha besar, menengah dan kecil sebagai informan penelitian di kampung batik Laweyan.

(2) Menentukan lima informan lain yang terkait langsung pada jaringan-jaringan personal dalam produksi dan perdagangan batik Laweyan. Informan tersebut meliputi tokoh Paguyuban Kampung Wisata Batik Laweyan, tokoh-tokoh senior di bidang batik, Disperindagkop dan Dinas Kebudayaan.

(3) Dari informan-informan tersebut akan diketahui budaya ekonomi pengusaha batik Laweyan. 
b. Tahap kedua

Menganalisis kebijakan pemerintah tentang industri batik, baik kebijakan yang berdampak positif dan berdampak negatif pada pengusaha batik Laweyan.

c. Tahap ketiga

Dalam tahap ini dilakukan analisis kebjakan pemerintah yang berdampak negatif terutama yang berhubungan dengan perdagangan bebas dan membandingkan antara tahap pertama dan kedua untuk mengetahui strategi-strategi yang digunakan oleh pengusaha batik Laweyan agar mereka tetap bertahan. Metoda yang digunakan adalah metoda penelitian deskriptif.

\section{PEMBAHASAN}

\section{Gambaran Kampung Batik Laweyan}

Kampung Batik Laweyan adalah kampung batik tertua dan menjadi pusat industri batik tradisional di Indonesia. Letaknya strategis, yaitu antara Kota Solo dengan Kabupaten Sukoharjo. Laweyan masih menampakan ciri khas usaha batik kuno yang tersedia cukup lengkap, seperti rumah-rumah kuno, bekas bangunan pabrik yang beralih fungsi, lorong-lorong dan gang yang menyerupai benteng jaman Belanda, monumen, makam para leluhur, masjid, langgar serta beberapa tempat atau rumah-rumah penduduk yang masih aktif mengembangkan industri batik rumah tangga, baik batik tulis, printing maupun cap. Setelah mengalami mati suri selama 30 tahun, pada tahun 2000 beberapa masyarakat Laweyan mulai merintis lagi usahanya. Usaha ini juga mendapat sambutan baik dari pemerintah Surakarta, dimana mereka mulai berbenah dengan ditetapkannya Kampung Laweyan sebagai Kampung Wisata Batik pada tahun 2004. Dengan wacana yang baru, mereka mulai membuka diri untuk memamerkan proses pembuatan batik baik batik tulis, cap, sablon, tolet, printing serta produk batik dalam ruang pamer yang ditata dengan indah. Perkembangan usaha ini dapat dilihat dari meningkatnya jumlah usaha dagang. Jenis produksi unggulan adalah batik tulis tradisional dengan ciri khas warnanya yang cenderung agak gelap, meliputi perpaduan antara warna coklat maupun kebiruan.

\section{Jaringan Usaha Batik}

Pengusaha batik Laweyan memerlukan jaringan-jaringan usaha agar usaha yang dijalankan dapat berjalan dengan baik. Unit-unit usaha yang terkait dalam pembuatan batik tulis tradisional adalah juragan batik, saudagar pemroses, carik/mandor penggarap dan pengrajin batik. Adapun jaringan usaha batik tulis tradisional dibahas dakan uraian selanjutnya.

\section{Jaringan Hubungan Pembelian Bahan Baku}

Pengusaha batik pemroses atau disebut juragan menjalin hubungan dagang dengan pedagang bahan baku kain berdasarkan ikatan kekerabatan, ketetanggaan dan 
pertemanan. Pembelian bahan baku kain dilakukan secara ngalap nyaur atau ambil barang dahulu, kemudian dibayar dengan tempo satu, dua atau tiga bulan. Hal ini disebabkan modal dari pengusaha batik digunakan untuk keperluan yang lain terlebih dahulu atau karena modal yang terbatas.

Pandangan pedagang kain terhadap hubungan dagang ngalap nyaur bahan baku kain merupakan sikap perlakuan tepo seliro. Perlakuan ini memandang segala sesuatu hal dari sudut pandang dirinya sendiri (nepakke selirone) dimana mereka akan merasa senang dan bahagia jika orang lain berperilaku baik terhadap dirinya, mereka hendaknya juga berusaha bersikap baik terhadap orang lain. Hubunganhubungan dagang ngalap nyaur bersifat multicomplex relationship, berarti banyak kondisi kebersamaan dan banyak tali pengikat diantara aktor-aktor yang membentuk hubungan dagang ngalap nyaur. Hubungan ini mempunyai sifat saling percaya, tolong-menolong dan kerja sama yang saling menguntungkan.

\section{Jaringan Hubungan Dalam Proses Produksi}

Sistem produksi adalah rangkaian hubungan relasional antar unit-unit produksi didalam suatu proses produksi. Pertumbuhan sistem produksi dari home industry ke putting out (Schneider) mengakibatkan peningkatan unit-unit usaha produsen batik seperti pengusaha batik atau juragan, saudagar pemroses, carik atau mandor penggarap dan pengrajin batik rumahan. Pertumbuhan unit-unit usaha produsen meningkatkan dinamika jalinan hubungan diantara mereka. Dinamika jaringan sosial produsen merupakan proses berkembangnya variasi pola khusus dari hubungan diantara produsen yang memiliki bentuk sebagai suatu kesatuan dengan karakteristik sosial budaya yang unik.

1. Jaringan hubungan proses produksi dengan sistem nempakke

Apabila pengusaha atau juragan batik/saudagar pemroses mendapatkan permintaan pesanan batik yang melebihi kapasitas produksi harian atau stok barang yang dimiliki, maka pengusaha tersebut akan membangun pola hubungan produksi dengan sistem nempakke atau ndandakke. Pengusaha akan menentukan motif dan desain batik yang diinginkan untuk kemudian dikerjakan oleh pengusaha batik lainnya yang memiliki kapasitas produksi lebih besar. Pengusaha pemroses membangun hubungan-hubungan produksi dengan mandor penggarap dan pengrajin batik pocokkan dengan system kontrak borongan.

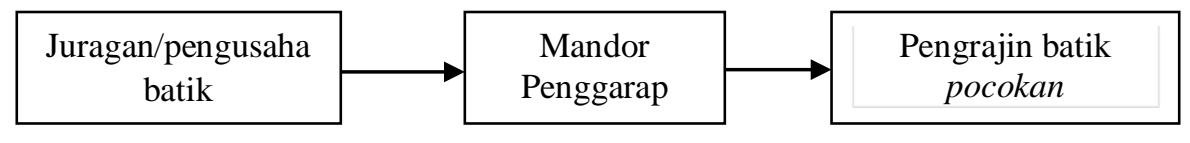

Gambar 2

Aliran Proses Produksi pada Sistem Nempakke atau Ndandakke

2. Jaringan hubungan proses produksi dengan sistem cluster

Jaringan hubungan proses produksi dengan sistem cluster adalah rangkaian hubungan produksi antara pengusaha dengan beberapa carik. Seorang carik sebagai 
supervisor bekerja dengan membawahi satu kelompok yang terdiri dari 10-15 pengrajin batik rumahan. Alasan perusahaan batik membangun sistem cluster adalah untuk dapat menekan upah tenaga kerja, seperti menghilangkan biaya transportasi, konsumsi, mengurangi biaya kesehatan dan risiko (biaya tenaga kerja) karena fluktuasi permintaan pelanggan.

\section{Jaringan hubungan proses produksi dengan sistem susukan}

Hubungan produksi antara juragan dengan pengrajin batik susukan berdasarkan kontrak borongan lepas. Masing-masing pihak saling terkait dalam menghasilkan sehelai kain batik tulis atau sinjang. Pengrajin batik susukan adalah ibu rumah tangga yang memanfaatkan waktu luangnya untuk membatik. Pengrajin batik susukan menghasilkan produk batik setengah jadi atau kain yang telah dicorek pola batik, dibatik dan diterusi namun belum diwarnai dan dilorot. Pengrajin batik susukan menjual produk setengah jadi tersebut kepada juragan batik. Juragan membayar kepada pengrajin batik susukan dalam bentuk kain, lilin malam dan uang tunai.

4. Jaringan hubungan proses produksi dengan sistem pocokan

Istilah pocokan berarti memperkerjakan seseorang berdasarkan kontrak borongan sesuai dengan kebutuhan juragan batik. Pekerjaan ngengreng pola batik, mbatik, nerusi, nglowong dilakukan di rumah pengrajin batik, sedangkan pekerjaan medel, mbironi, nyoga sampai dengan nglorot dikerjakan pada unit usaha juragan. Pada umumnya hubungan produksi pocokan terbentuk karena juragan mendapatkan pesanan batik dalam jumlah relatif besar melebihi kaapasitas produksi yang dapat dihasilkannya.

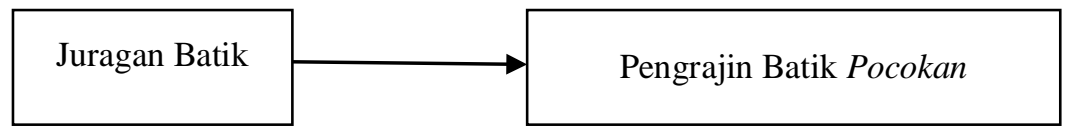

Sumber: Wijaya (2008)

\section{Aliran Hubungan Proses Produksi Sistem Pocokan}

Hubungan proses produksi dengan sistem pocokan dilakukan berdasarkan kontrak borongan. Besarnya upah ditentukan berdasarkan satuan hasil kerja yang dapat diselesaikan pengrajin batik pocokan.

5. Jaringan hubungan proses produksi dengan sistem pabrikan

Juragan atau pengusaha batik membangun hubungan proses produksi dengan sistem pabrikan secara terpusat dengan tujuan untuk kepentingan ekonomi perusahaan. Pola hubungan produksi secara ketergantungan berjenjang adalah pertama hubungan pemilik perusahaan dengan manajer, kedua hubungan manajer dengan supervisor, ketiga hubungan supervisor dengan pengrajin batik dan tukang. Hak-hak dan kewajiban tenaga kerja termuat dalam Kesepakatan Kerja Bersama (KKB) perusahaan. 
Berbagai sistem jaringan diatas seperti nempakke, cluster, kontrak borongan dan pabrikan sebagai salah satu saluran untuk meminimalisasi pengeluaran dan memaksimal penerimaan. Keragaman sistem hubungan proses produksi ini memungkinkan juragan atau saudagar pemroses menyesuaikan diri dalam menghadapi fluktuasi permintaan pelanggan batik. Sebaliknya pengrajin batik memiliki beragam alternatif pilihan untuk terlibat dalam jaringan hubungan proses produksi untuk memperoleh pekerjaan dan pendapatan ekonomi rumah tangganya.

\section{Jaringan Hubungan Dagang Batik}

Perkembangan sistem produksi dari home industry, putting out system dan pabrikan manufaktur meningkatkan jaringan perdagangan batik dari lokal sampai domestik-ekspor. Penjualan batik di Laweyan dilakukan dengan beberapa cara yaitu antara lain:

a. jaringan hubungan dagang dengan penjualan langsung

b. jaringan hubungan dagang antara juragan batik dengan saudagar batik di Pasar

Klewer

c. hubungan langganan tetep ngalap nyaur

Hubungan dagang antara juragan batik dan saudagar batik (bisa saudagar distributor, bakul batik) dengan sistem langganan tetep ngalap nyaur berdasarkan ikatan kekerabatan dan ketetanggaan. Hubungan dagang kios murni sebagai distributor dengan saudagar batik dan bakul batik bersifat ngalap nyaur. Saudagar batik dan bakul batik diberi kelonggaran waktu untuk membayar selama seminggu. Keuntungan dari saudagar distributor adalah penjualan barang dapat berjalan lancar dan kepastian uang kontan diterima. Saudagar dan bakul batik merasa untung karena mendapat kredit barang tanpa bunga dan menambah modal barang dagangan.

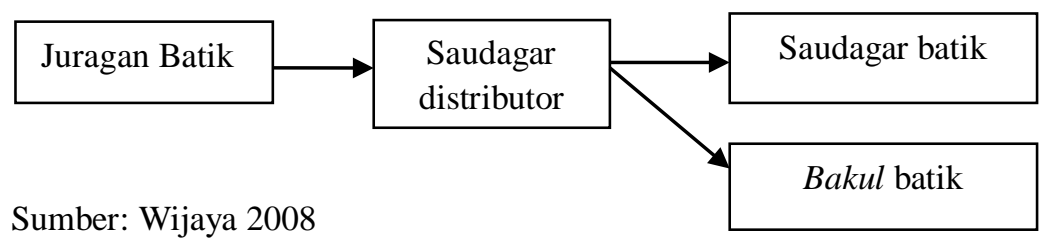

\section{Gambar 4}

Aliran Hubungan antara Juragan Batik dengan Saudagar Distributor

d. Hubungan dengan sistem nitip

Hubungan dagang dengan sistem nitip terbentuk dari pengalaman kerjasama yang relatif lama dan panjang. Pengalaman hubungan dagang tersebut terbentuk atas asas saling percaya, berbagi risiko dan saling berbagi keuntungan. Hubungan dagang nitip bersifat tertutup, monopoli dan rutin. Aliran hubungan nitip adalah sebagai berikut. 


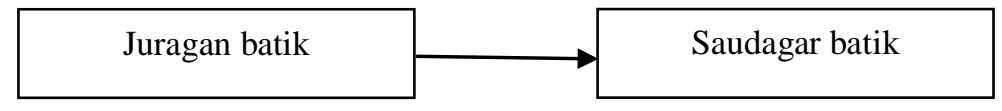

Sumber: Wijaya 2008

\section{Gambar 5}

Aliran Hubungan Nitip

e. Jaringan hubungan dagang antara pengusaha batik dengan saudagar batik di luar kota

Hubungan dagang antara pengusaha batik Laweyan dengan saudagar batik di luar kota dengan menggunakan hubungan sistem "korwil” (koordinator wilayah). Juragan batik membangun saluran distribusi batik melalui beberapa saudagar sebagai koordinator wilayah dagang di kotanya masing-masing. Pengusaha memasok barang dagangan pada awal bulan dan saudagar "korwil" membayar barang dagangan tersebut satu bulan kemudian.

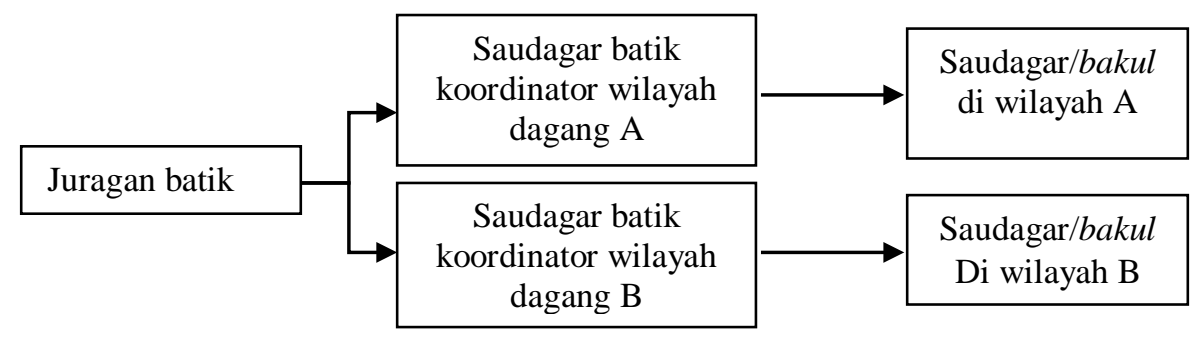

Sumber: Wijaya (2008)

\section{Gambar 6 \\ Aliran Hubungan dengan Sistem "Korwil”}

Landasan utama jaringan hubungan relasional pedagang dengan sistem "korwil" berdasarkan pengalaman hubungan dagang yang lama dan panjang. Hubungan dagang antara juragan dengan saudagar "korwil" harus disiplin, jujur, berprestasi, saling percaya, timbal balik dan kerjasama tim. Juragan menciptakan standardisasi pengiriman barang dagangan, kualitas produk, harga satuan produk dan keuntungan persatuan produk. Barang dagangan diusahakan bervariasi sesuai dengan permintaan pelanggan di wilayah masing-masing.

Keuntungan bagi saudagar "korwil" adalah kesempatan memperoleh persediaan barang dagangan sesuai dengan permintaannya secara teratur, memperoleh potongan harga dan informasi patokan harga barang dagangan. Sedangkan keuntungan juragan batik adalah memperoleh kepastian aliran barang dagangan dan uang kontan yang teratur, mengurangi risiko perdagangan serta mengurangi biaya promosi.

\section{Perubahan-Perubahan Struktur Politik (Kebijakan) yang Memengaruhi Perkembangan Usaha Batik Laweyan}

Perkembangan industri batik Laweyan selain dipengaruhi oleh budaya ekonominya juga secara tidak langsung dipengaruhi oleh kebijakan pemerintah. 


\section{Kebijakan Pemerintah Yang Mendukung Industri Batik}

Berlakunya UU No.22/1999 tentang Otonomi Daerah yang direvisi menjadi UU No.32/2004 serta UU No.25 tahun 1999 tentang Perimbangan Keuangan Antara Pusat dan Daerah yang juga direvisi menjadi UU No.33/2004, diharapkan dapat tepat sasaran dan mampu mengoptimalkan dukungan dana khususnya untuk pengembangan batik Laweyan sebagai potensi daerah yang dapat dijadikan sebagai salah satu bagian sumber pendapatan daerah khususnya melalui Pendapatan Asli Daerah (PAD). Perkembangan batik ini juga didukung dengan adanya pengakuan dari UNESCO pada tanggal 2 Oktober 2009 dimana batik merupakan ciri khas budaya bangsa Indonesia yang juga sebagai warisan budaya dunia, dan pemerintah menetapkan pada tanggal 2 Oktober sebagai Hati Batik Nasional.

Surakarta memiliki sumber daya dan potensi ekonomi yang cukup baik, namun banyak yang belum dikelola secara optimal. Salah satunya adalah tentang potensi batik. Dalam sejarahnya, kampung Laweyan dikenal sebagai pusat industri batik, karena hampir semua penduduknya berprofesi sebagai pengusaha batik. Batik merupakan warisan dari nenek moyang yang telah berkembang sejalan dengan proses waktu, dimana industri batik juga mengalami berbagai pasang surut. Untuk itu dilakukan usaha-usaha dalam mengembangkan dan melestarikan batik sebagai salah satu budaya bangsa agar tidak begitu saja tergerus dan tertelan oleh budaya bangsa lain yang mengatas namakan modernisasi.

Upaya pemerintah Kota Surakarta melalui dinas maupun lembaga terkait dalam rangka mengatasi kendala yang dihadapi oleh pelaku industri batik di kampung batik Laweyan Surakarta anata lain:

1. Meningkatkan peran promosi dan perluasan pangsa pasar, yang terdiri dari:

a. Kaitannya dengan produk batik.

1). Mengadakan kegiatan pameran.

2). Mengadakan kegiatan misi dagang

3). Mendaftarkan HAKI atas motif-motif batik kuno.

4). Menetapkan seragam pakaian batik pada hari-hari tertentu bagi pegawai pada instansi pemerintah.

b. Kaitannya dengan potensi pariwisata kampung batik Laweyan.

1) Mendatangkan tamu-tamu penting yang berkunjung ke Surakarta.

2) Pembuatan grand design kampung batik Laweyan.

3) Promosi melalui media cetak.

4) Penambahan fasilitas-fasilitas pendukung.

5) Upaya revitalisasi bangunan-bangunan kuno kampung batik Laweyan 
2. Membantu perkuatan permodalan usaha melalui akses dengan BUMN.

3. Mengembangkan kualitas sumber daya manusia serta peningkatan kemampuan manajerial dan kewirausahaan bagi pelaku usaha, meliputi:

a. Pelatihan manajemen usaha.

b. Mengadakan kegiatan temu usaha dan seminar kewirausahaan.

c. Mengadakan pendidikan dan pelatihan tentang pencampuran warna batik.

d. Mengadakan kegiatan studi banding.

e. Kebijakan pemerintah dalam menangani pencemaran air limbah batik di Kota Surakarta.

\section{Kebijakan Pemerintah yang Berdampak Negatif terhadap Industri Batik Laweyan}

Industri batik Laweyan diharapkan dapat mengantisipasi perubahan tatanan ekonomi dunia, yang ditandai dengan adanya globalisasi dan perdagangan bebas yang tidak lagi mengenal batas wilayah atau negara. Keadaan ini telah melahirkan perubahan nyata pada kehidupan sosial dan budaya masyarakat (Nugroho 1997).

Pada bulan Januari 2010 berlaku perdagangan bebas antara ASEAN dan Cina, sehingga produk-produk Cina menjadi sangat mudah untuk masuk ke Indonesia. Penerapan China-ASEAN Free Trade Area (CAFTA) merupakan mimpi buruk bagi produsen lokal. Walaupun pemerintah telah menyatakan siap terhadap dampak negatif dari CAFTA, namun tidak demikian dengan produsen lokal. Mereka tetap khawatir terhadap ekspansi produk Cina besar-besaran pasca diberlakukannya CAFTA. Dalam kenyataannya, produk tekstil Cina sudah memasuki pasar-pasar tradisional yang akan mengancam produk lokal, sampai saat ini pengusaha batik Laweyan belum merasakan dampak masuknya batik Cina di pasaran.

Dalam menghadapi diterapkannya MEA 2015, masyarakat kampung batik Laweyan telah mempunyai strategi yang dapat memperkuat industri batik mereka.

\section{Strategi-Strategi yang Diterapkan oleh Pengusaha Batik Laweyan dalam Menghadapi Perdagangan Bebas}

Pengusaha batik Laweyan pada umumnya adalah industri batik skala kecil dan menengah, yang mana dalam menghadapi globalisasi diperlukan beberapa strategi prioritas yang digunakan strategi ini diarahkan dengan memperbaiki kelemahan dan memanfaatkan peluang yang ada. Strategi yang digunakan adalah penguatan kerja sama, penguatan pasar, peningkatan kapasitas sumber daya manusia, penciptaan iklim usaha yang kondusif dan penguatan modal sosial.

Strategi pertama adalah penguatan kerja sama. Pengembangan industri batik Laweyan tidak dapat dilakukan sendiri oleh pengusaha batik saja tetapi memerlukan sinergi semua pihak. Kerja sama yang kuat antar pelaku-pelaku yang terkait dalam 
pengembangan industri batik memerlukan satu visi bersama. Pelaku-pelaku yang terkait diantaranya pengusaha industri batik Laweyan yang terdiri dari perwakilan industri batik skala kecil, menengah dan besar; industri pendukung (pembeli, pemasok bahan baku, bahan penolong); serta pemerintah yaitu Bappeda, Dinas Perindustrian dan Perdagangan, Dinas Koperasi, Dinas Pariwisata, lembaga keuangan, lembaga pendidikan dan pelatihan, asosiasi usaha, lembaga bantuan pengembangan bisnis. Pengusaha batik Laweyan memerlukan beberapa strategi prioritas yang digunakan, yang diarahkan dengan memperbaiki kelemahan dan memanfaatkan peluang yang ada.

Strategi kedua adalah penguatan pasar. Penanganan pemasaran menjadi prioritas karena jika produk batik Laweyan mempunyai pasar yang jelas, maka akan terjadi kesinambungan proses produksi. Dengan demikian, usaha batik akan berkembang, permasalahan keuangan dapat teratasi dan kesejahteraan tenaga kerja dapat meningkat. Agar memiliki pasar yang jelas, setiap industri batik Laweyan harus mempunyai karakter batik tersendiri (produk yang terdiferensiasi).

Strategi ketiga adalah peningkatan kapasitas sumber daya manusia. Peningkatan kapasitas sumber daya manusia sangat penting bagi pengembangan industri batik Laweyan karena manusia merupakan penggerak, pemberi keputusan dan pelaku dari setiap kegiatan. Usaha akan berkembang dengan baik jika pelaku tersebut memiliki motivasi, serta memiliki pendidikan dan pengetahuan akan manajemen usaha dan teknologi. Untuk mengembangkan kemampuan dari karyawan, para pengusaha batik Laweyan berupaya mengikuti pelatihan-pelatihan yang diadakan oleh forum atau dinas-dinas terkait, misalnya pelatihan tentang desain, pewarnaan alam yang diselenggarakan oleh Disperindag.

Strategi keempat adalah penciptaan iklim usaha yang kondusif. Penciptaan iklim usaha yang kondusif diperlukan untuk mewujudkan industri batik yang efisien, dinamis, berdaya saing, serta dapat menarik investor yang dapat membantu masalah permodalan yang banyak di hadapi oleh industri batik skala kecil. Terciptanya iklim usaha yang kondusif guna kelancaran pelaksanaan dan pengembangan usaha penting dalam menarik investor untuk berinvestasi di industri batik Laweyan.

Strategi kelima adalah penguatan social capital (modal sosial) pengusaha batik Laweyan. Modal sosial adalah sebuah barang publik (public good) yang di bangun oleh masyarakat. Sumber dari modal sosial adalah norma dan kepercayaan (trust) di mana kedua aspek tersebut yang mendasari kerjasama dan aksi bersama (collective action) untuk mencapai kemanfaatan.

Modal sosial ini merupakan kunci perekat yang mengikat warga masyarakat secara bersama, menjadi kumpulan dan jaringan sosial, institusi, norma-norma (seperti kerja sama) dan nilai-nilai atau atribut sosial (khususnya trust). Modal sosial pengusaha batik Laweyan terlihat apabila dari beberapa pengusaha batik Laweyan mempunyai kesulitan pengadaan bahan baku mori, maka pengusaha tersebut 
membeli secara angsuran atau dibayar setelah barang laku. Dalam modal sosial, pengusaha batik Laweyan memegang teguh kepercayaan (trust) yang telah diberikan oleh pengusaha lain sehingga bila membutuhkan bantuan bahan baku dapat meminjam dari pengusaha lain.

\section{SIMPULAN DAN IMPLIKASI}

\section{Simpulan}

Perkembangan usaha dari industri rumahan ke pabrikan ini menyebabkan pengusaha batik mendapatkan keuntungan yang berlipat-lipat sehingga terjadi perubahan perekonomian pengusaha. Perubahan ini membedakan sistem ekonomi yang dilakukan juragan dengan tenaga kerja upahan atau pengrajin batik. Juragan di menginginkan keuntungan sebesar besarnya, sedangkan pengrajin batik berbasis ekonomi rumah tangga. Ekonomi pengrajin batik mendekati tipe ekonomi bazaar sedangkan juragan batik mendekati tipe ekonomi firma. Kedua tipe tersebut memiliki mekanisme ekonomi sendiri-sendiri dan terpisah satu sama lain, tetapi penelitian ini menunjukkan bahwa meskipun juragan dan pengrajin batik memiliki mode ekonomi sendiri-sendiri tetapi diantara mereka saling berhubungan satu sama lain, yang ditunjukkan pada jaringan hubungan dagang langganan tetap ngalap nyaur antar juragan dan pengrajin batik rumahan. Dapat dilihat bahwa budaya ekonomi batik Laweyan mempunyai ciri tersendiri yaitu budaya ekonomi bazaar dengan hubungan sosial mereka yang lebih bersifat resiprokal.

Hubungan sosial tetangga, kekerabatan dan keagamaan mengikat tindakan ekonomi. Hubungan tolong-menolong berbasis ikatan sosial dan trust mengikat dalam tindakan ekonomi juragan batik. Juragan, saudagar pemroses dan pengrajin batik mengembangkan jaringan hubungan dagang nitip. Menurut pandangan para aktor ekonomi usaha batik nitip mempunyai makna antara hubungan di antara para pelaku usaha batik yang saling melekat atau saling mengikat dan saling menguntungkan satu sama lain (mutual sided embedded). Penelitian ini menunjukkan konsep keterlekatan perilaku ekonomi dalam hubungan-hubungan sosial.

Kecenderungan berbagai pola jaringan hubungan produksi dan hubungan dagang mengarah pada struktur jaringan sosial personal. Individu membangun jaringan berjenjang antara pusat, broker dan partisipan sebagai alat mengembangkan kepentingan egonya. Jaringan sosial personal dibangun atas dasar prakarsa dan kepentingan egosentris individu. Dalam penelitian ini struktur jaringan hubungan dagang cenderung horizontal dengan perbedaan akses ekonomi pasar lokal. Sebaliknya struktur jaringan produksi cenderung vertikal, di mana posisi pusat cenderung mengendalikan hubungan-hubungan produksi sehingga broker dan partisipan semakin tergantung terhadap pusat. Jaringan yang kuat baik secara horizontal dan vertikal yang dilakukan oleh pengusaha batik Laweyan membuat ikatan yang kuat antar pengusaha maupun pengusaha dengan buruhnya. 
Selain adanya ikatan yang kuat serta trust antar pengusaha maupun pekerja batik ini, keberadaan pengusaha batik Laweyan juga didukung oleh pemerintah melalui kebijakan-kebijakan yang dibuatnya, seperti kebijakan pemerintah yang tertuang dalam UU No. 25 Tahun 1999 dan UU No.33 tahun 2004 Tentang Dana Perimbangan dengan diikuti kebijakan pemerintah daerah berupa perda tentang APBD dan kebijakan lainnya. Hal ini merupakan kebijakan penting yang diharapkan mampu mengantisipasi era perdagangan bebas. Ketepatan alokasi anggaran pada dana perimbangan tersebut memegang peranan yang penting dalam meningkatkan usaha batik Laweyan dan sekitarnya. Salah satu kebijakan pemerintah provinsi maupun pemerintah daerah adalah dengan mengharuskan pegawainya untuk berseragam batik pada hari-hari tertentu.

\section{Implikasi Hasil Penelitian}

Pengusaha batik Laweyan sebaiknya banyak melakukan inovasi-inovasi produk batik dengan merespon permintaan pasar, mengadopsi penggunaan teknologi modern dalam design, cara berproduksi dan pemasarannya. Penggunaan warna alam sebaiknya diupayakan untuk ditingkatkan guna mengantisipasi green product yang sudah menjadi issue global. Penggunaan manajemen modern perlu ditingkatkan agar usaha batik Laweyan lebih efisien, efektif dan kompetitif.

Bagi pemerintah, diharapkan dapat lebih teliti lagi dalam merumuskan kebijakan, sehingga antara aspirasi pengusaha batik Laweyan dengan kebijakankebijakan yang dibuat pemerintah menjadi sinkron. Pemerintah hendaknya juga meningkatkan kampanyenya dalam penggunaan produk-produk dalam negeri.

\section{DAFTAR PUSTAKA}

Dunn, W. N. 2004. Public Policy Analysis: An Introduction Third Edision. New Jersey: Pearson Prentice Hall.

Hart, G. 1989. Agrarian Change in the Context of State Patronage, in Hart, G., Andre Turton,and Benjamin White (eds). Agrarian Transformations: Local Processes and the State in Southeast Asia. Berkeley: University of California Press.

Meleong, L. J. 2000. Metodologi Penelitian Kualitatif. Bandung: PT Remaja Rosdakarya.

Polanyi, K.1957. The Great Transformation. Boston Beacon Press.

Prasetyo, A. 2010. Batik Karya Agung Warisan Budaya Dunia. Pura Pusaka.

Suharsono. 2008. Analisis Kebijakan Publik. Yogyakarta: Pustaka Pelajar.

Undang-Undang Republik Indonesia Nomor 22 Tahun 1999 tentang Pemerintah Daerah. 
Undang-Undang Republik Indonesia Nomor 33 Tahun 2004 tentang Perimbangan Keuangan Pemerintah Pusat dan Pemerintah Daerah. 